\title{
Evaluation of Our Neuronavigation Assisted Biopsy Results According to Lesion Location and Size
}

\author{
Nöronavigasyon ile Biyopsi Sonuçlarımızın Lezyon Yeri ve Boyutuna \\ Göre Değerlendirilmesi
}

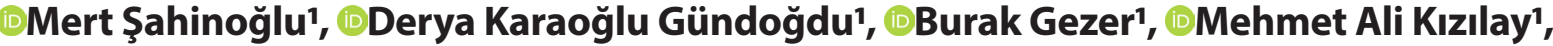

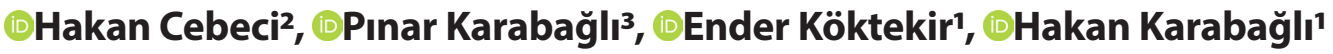 \\ 'Selçuk University, Medical Faculty, Department of Neurosurgery, Konya, Turkey \\ ${ }^{2}$ Selçuk University, Medical Faculty, Department of Radiology, Konya, Turkey \\ ${ }^{3}$ Selçuk University, Medical Faculty, Department of Pathology, Konya, Turkey
}

\begin{abstract}
Purpose: Since neuronavigation assisted intracerebral biopsy is an often-used method in deeper and smaller lesions, it may cause radiological and neurological complications in patients. Also, since it is a minimally invasive method, tissue sampling is limited, and a definite histopathological diagnosis may not be possible for every biopsy. In this study, we aimed to examine how NNAB results is affected by the lesion's localization and size.

Material and Method: The files of 41 patients who underwent neuronavigation assisted intracerebral tissue biopsy between 2016 and May 2021 were reviewed retrospectively. Patients who underwent biopsy with frameless neuronavigation were included in the study. The determined parameters were evaluated according to the localization of the lesions, presence in the eloquent area, and lesion size.

Results: 20 (63.41\%) lesions out of 41 patients included in the study were localized in the eloquent area, while the lesions of 15 (36.58\%) were outside the eloquent area. The mean lesion size was $34 \times 27.76 \mathrm{~mm}$. The tissue samples of $38(92.68 \%)$ patients received a diagnosis. Postoperative control CT scans showed radiological complications in $4(9.75 \%)$ patients. Three $(7.31 \%)$ patients had postoperative neurological complications. No biopsy-related mortality was observed.

Conclusion: Adequate planning and examination of radiological images by both the radiologist and the surgeon before surgery reduce the risk of radiological and neurological complications caused by the lesion's small size and eloquent area localization. Biopsy of the target tissue from more than one quadrant provides sufficient tissue for histopathological diagnosis and helps to make a more accurate diagnosis.
\end{abstract}

Keywords: Biopsy, frameless, Intracerebral, neuronavigation

\section{Öz}

Amaç: Nöronavigasyon ile intraserebral biyopsi sıklıkla daha derindeki ve ufak boyuttaki lezyonlarda kullanılan bir yöntem olduğu için hastalarda radyolojik ve nörolojik komplikasyonlar oluşturabilmektedir Ayrıca minimal invaziv bir yöntem olduğu için kısıtlı doku örneği alınabilir ve buna bağlı histopatolojik tanı koyulmayabilir. Biz de bu çalışmayla nöronavigasyon ile intraserebral biyopsi sonuçlarımızın lezyon lokalizasyonuna ve boyutuna bağı ne kadar etkilendiğini ortaya koymaya çalıştık.

Gereç ve Yöntem: 2016 ve Mayıs 2021 yılları arasında bu yöntem ile opere edilmiş 41 hastanın dosyaları retrospektif olarak incelendi. Çalışmaya çerçevesiz nöronavigasyon ile biyopsi alınan hastalar dahil edildi. Belirlenen parametreler lezyonların yerine, hassas bölgede olup olmamasına ve boyutlarına göre değerlendirildi.

Bulgular: Çalışmaya dahil edilen 41 hastanın $26(\% 63,41)^{\prime}$ sının lezyonu hassas bölge, 15 (\%36,58)' nin lezyonu ise hassas bölge dışı yerleşimliydi. Lezyon boyutları ortalama 34×27,76 mm idi. 38 (\%92,68) hastanın doku örneklerine tanı koyulabildiği tesbit edildi. Operasyon sonrası çekilen kontrol BT' lerde $4(\% 9,75)$ hastada radyolojik olarak komplikasyon görüldü. $3(\% 7,31)$ hastada ise operasyon sonrası nörolojik komplikasyon mevcuttu. Cerrahiye bağlı mortaliteye rastlanmadı.

Sonuç: Cerrahi öncesi iyi planlama ve radyolojik görüntülerin hem radyolog hem de cerrah tarafindan iyi incelenmesi lezyonun hassas bölgede ve küçük boyutta olmasının getirdiği radyolojik ve nörolojik komplikasyon riskini azaltmaktadır. Hedef dokudan birden fazla kadrandan biyopsi alınması histopatolojik tanı için yeterli doku elde edilmesini sağlar ve doğru tanı koyulmasına çok daha fazla yardımcı olur.

Anahtar Kelimeler: Biyopsi, çerçevesiz, intraserebral, nöronavigasyon

Corresponding (illetişim): Mert Şahinoğlu, Selçuk Üniversitesi Tıp Fakültesi Hastanesi, E Blok, Zemin Kat, Beyin ve Sinir Cerrahisi Polikliniği, Selçuklu, Konya, Türkiye

E-mail (E-posta): msahinoglu09@gmail.com

Received (Geliş Tarihi): 15.06.2021 Accepted (Kabul Tarihi): 29.06.2021 


\section{INTRODUCTION}

Neuronavigation assisted biopsy (NNAB) is a minimally invasive method that has been used more frequently with the development of technology for cerebral lesions that cannot be operated on with open surgery or that do not require surgery but need tissue diagnosis. ${ }^{[1]}$ Excision with craniotomy is very convenient in patients with a deep-localized lesion, lesions located in more eloquent areas, small lesions, and/ or high comorbidities. Besides, it helps to obtain accurate tissue diagnosis of diseases with challenging diagnosis and whose primary treatment is not surgical, such as primary central system lymphoma or neurodegenerative diseases. In particular, NNAB procedures performed without a stereotaxy frame have become highly preferred due to the patient's comfort and less complication risk. ${ }^{[2]}$

Through this method, it is imperative to take a sufficient amount of tissue sample from the right place without harming the patient. Although special magnetic resonance imaging (MRI) is used for this purpose and pre-intervention plans are made, neurological and/or radiological complications may develop due to the small lesion sizes and lesion localization such as the motor cortex, basal ganglia, thalamus, or corpus callosum. ${ }^{[3]}$ Also, inadequate or inaccurate pathological results may occur.

To the best of our knowledge, we did not find such a detailed study about frameless NNAB, especially based on the location and size of the lesion. In this study, we examined how the success of NNAB procedures performed in our clinic is affected by the localization and size of the lesion.

\section{MATERIAL AND METHOD}

The study was carried out with the permission of Selcuk University Rectorate Local Ethics Committee (Date: 09.06.2021, Decision no: 2021/35). All procedures were performed adhered to the ethical rules and the Helsinki Declaration of Principles.

The files of 41 patients who underwent neuronavigation assisted intracerebral biopsy in our clinic between 2016 and May 2021 were reviewed retrospectively. Patients who underwent NNAB without stereotaxy frame were included in the study. The gender, age, pre-operative presence of neurodeficiency, anatomical localization, and size of the intracerebral lesion/lesions were evaluated. The anatomical localization of the lesions was divided into two groups as the eloquent area or not the eloquent area. Deeply located lesions, such as the motor cortex, basal ganglia, internalexternal capsule, thalamus, caudate nucleus, corpus callosum, and Wernicke-Broca that are likely to cause neurodeficiency in the patient, were defined as eloquent areas (Figure 1). Also, whether the lesions were multiple, whether the primary of the lesion was known or not, the reported MR spectroscopy results before the operation, and the pathology reports of the tissue samples were examined. Postoperative computed tomography (CT) scans were performed to determine whether there were radiological complications and how much the cystic contents of cystic lesions could be evacuated. Additionally, it was determined by examining the neurological examinations after the operation whether there were neurological complications related to the procedure. The presence of any wound complication was also examined. Patients' postoperative length of hospitalization in Neurosurgery Clinic and in the hospital was also determined.

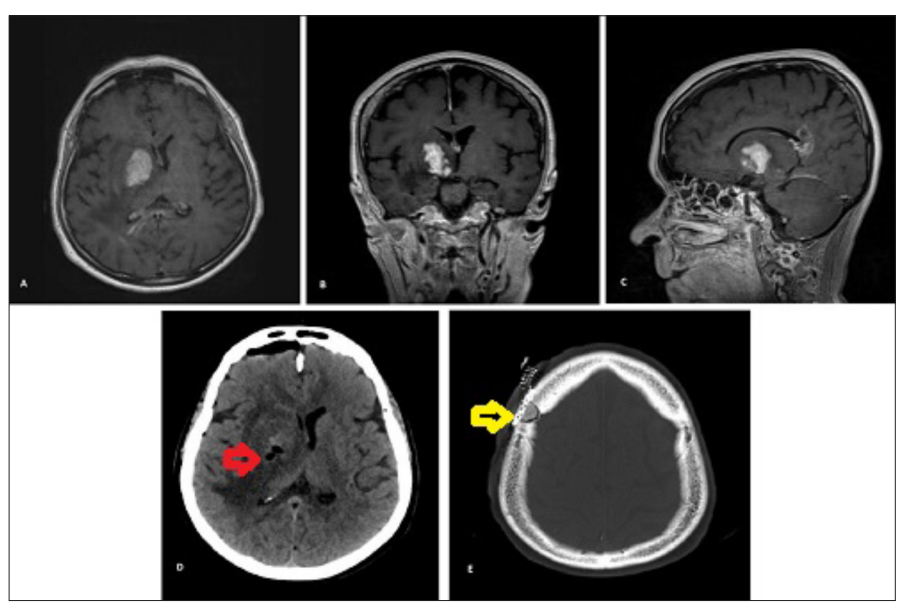

Figure 1. (A) Hyperintense lesion in the right basal nucleus on contrastenhanced T1 sequence axial MRI, (B) coronal MRI, (C) sagittal MRI, (D) The area of the biopsy taken from the lesion in the postoperative early control cranial CT (red arrow), (E) Visualization of the entry point and burr hole plaque in the bone section of postoperative early control cranial CT (yellow arrow)

\section{Surgical Technique}

Standard procedure was used for each patient. Appropriate images were selected after the navigation compatible MRI taken the evening before the operation of the patients and were loaded into the neuronavigation device. Planning was done by selecting the entry point and the target point in a way that the lesion could be reached in the shortest possible way without causing any complication to the patient on the device's computer. During the planning, special attention was paid to the absence of intracerebral vascular structures in the trace reaching the target. Under general anesthesia, the patients' heads were fixated by a 3-pin spiked Mayfield to prevent disruption in navigation planning. The patients were given the appropriate position. Image matching was performed with the neuronavigation device.

The operation area of the patients was shaved, and the lesion was marked in this area. Patients were not administered any anti-cerebral edema medication during the surgical procedure. A linear incision of approximately $3 \mathrm{~cm}$ was made by centering the lesion. After reaching the bone tissue, the lesion location was confirmed by neuronavigation, and one burr hole was opened to this area with the help of an electric motor. After the dura was opened in the form of an envelope, the biopsy arm was fixed to minimize the margins of error indicated by the navigation device. The biopsy needle length was adjusted according to the distance to the lesion indicated 
by the neuronavigation device, and the biopsy needle was introduced through the cannula. Tissue samples were taken from 4 quadrants of the lesion and were sent to pathology for histopathological examination. While removing the cannula and biopsy needle, attention was paid to the presence of blood at the ends regarding the risk of hemorrhage. The opened dura was sutured if possible. In all cases, a hemostatic sponge was placed on this area. The bone powder obtained during the opening of the burr hole was filled in this area, and the round bone plate was fixed in the bur hole area. Galea was unconditionally sutured (Figure 2). The patients were extubated in the operating room and taken to the Neurosurgery Intensive Care Unit.
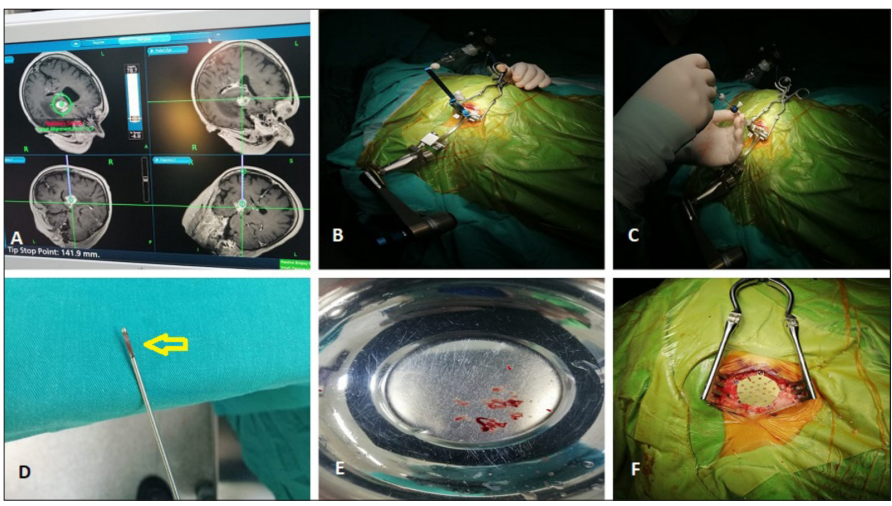

Figure 2. (A) Targeting and trajectory of the lesion on the monitor of the peroperative neuronavigation device, (B) Fixation of the biopsy arm by targeting the lesion, (C) Taking a biopsy with a biopsy needle, (D) Tissue sample taken at the tip of the biopsy needle, (E) Quantity of tissue samples from 4 quadrants, (F) Closure of the burr hole with a plaque after the completion of the biopsy

\section{Statistical Analysis}

Statistical analyzes were performed using SPSS version 18.0. The Chi-square test was used to compare categorical measurements. Fisher's Exact test result was interpreted in the presence of a cell with less than 5 in frequency in $2 \times 2$ tables in the chi-square test. Likelihood Ratio statistic was interpreted if there was no $2 \times 2$ table and less than five frequencies. The Mann-Whitney $U$ test was used for comparisons with the pathology results since the variables of age, lesion size, and length of stay in the hospital were quantitative data.

\section{RESULTS}

The mean age of 41 patients included in the study was 57.31 (minimum 11, highest 78) years. Twenty-five patients (60.97\%) were female, and 16 were male (39.02\%). Preoperatively, 22 (53.65\%) patients had low Glasgow Coma Score (GCS) and/or neurodeficiency. Intracerebral lesions were multiple localized in 10 (24.39\%) patients. Lesion biopsy localizations were as follows; corpus callosum localization in 7 (17.07\%), right basal ganglia in $4(9.75 \%)$, left basal ganglia in 1 (2.43\%), the right caudate nucleus in $2(4.87 \%)$, left caudate nucleus in $1(2.43 \%)$, right thalamus in $5(12.19 \%)$, and left thalamus in 3 (7.31\%). Also, lesion biopsies were taken from right frontal in $3(7.31 \%)$ patients, left frontal in $6(14.63 \%)$ patients, right parietal in $3(7.31 \%)$ patients, left parietal 1 (2.43\%) patient, left occipital in $2(4.87 \%)$ patients, the right temporooccipital in $1(2.43 \%)$ patient, and left temporal in $2(4.87 \%)$ patients. $26(63.41 \%)$ of these lesions were in the eloquent area, and $15(36.58 \%)$ were outside the eloquent area. When the cerebral region of the lesion and whether the tissue samples were histopathologically diagnosed or not, no statistically significant relationship was found between two of them ( $p>0.05)$ (Table 1). When we examine the relationship according to the presence of the lesion in the eloquent area or outside of the eloquent area and whether the tissue samples were histopathologically diagnosed or not, no significant relationship was found statistically again ( $p>0.05$ ) (Table $\mathbf{2}$ ).

Table 1. The statistical relationship between the location of lesions that have been biopsied and whether these lesions have a pathological diagnosis

\begin{tabular}{|c|c|c|c|c|c|}
\hline & & & $\begin{array}{c}\text { Path } \\
\text { Dia }\end{array}$ & $\begin{array}{l}\text { gical } \\
\text { osis }\end{array}$ & Total \\
\hline & & & No & Yes & \\
\hline & Cornuc Callorum & $\mathrm{n}$ & 0 & 7 & 7 \\
\hline & eorpus Caniosumi & $\%$ & $0.0 \%$ & $100.0 \%$ & $100.0 \%$ \\
\hline & Bight Racal Nucleus & $\mathrm{n}$ & 0 & 4 & 4 \\
\hline & . & $\%$ & $0.0 \%$ & $100.0 \%$ & $100.0 \%$ \\
\hline & Dight Frontoli aho & $\mathrm{n}$ & 1 & 2 & 3 \\
\hline & Rignit rionlal LODE & $\%$ & $33.3 \%$ & $66.7 \%$ & $100.0 \%$ \\
\hline & Dight Coudat Nuclaus & $\mathrm{n}$ & 0 & 2 & 2 \\
\hline & . & $\%$ & $0.0 \%$ & $100.0 \%$ & $100.0 \%$ \\
\hline & Piabt Ocrinitall obe & $\mathrm{n}$ & 0 & 2 & 2 \\
\hline & 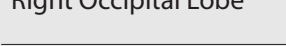 & $\%$ & $0.0 \%$ & $100.0 \%$ & $100.0 \%$ \\
\hline & Diabt Dariot 1 abro & $\mathrm{n}$ & 1 & 2 & 3 \\
\hline & Rignt Parletal Lode & $\%$ & $33.3 \%$ & $66.7 \%$ & $100.0 \%$ \\
\hline & Biaht Thalamus & $\mathrm{n}$ & 0 & 5 & 5 \\
\hline Lesion & nigiti milamins & $\%$ & $0.0 \%$ & $100.0 \%$ & $100.0 \%$ \\
\hline location & Pight Tomnoroccinital & $\mathrm{n}$ & 0 & 1 & 1 \\
\hline & 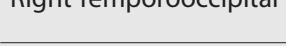 & $\%$ & $0.0 \%$ & $100.0 \%$ & $100.0 \%$ \\
\hline & I fft Rasal Nucleus & $\mathrm{n}$ & 0 & 1 & 1 \\
\hline & Leit Dasdi ivucieus & $\%$ & $0.0 \%$ & $100.0 \%$ & $100.0 \%$ \\
\hline & 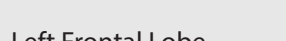 & $\mathrm{n}$ & 0 & 6 & 6 \\
\hline & Leti riomilal LODe & $\%$ & $0.0 \%$ & $100.0 \%$ & $100.0 \%$ \\
\hline & Left Caudat Nulous & $\mathrm{n}$ & 0 & 1 & 1 \\
\hline & Letl Caucat inucieus & $\%$ & $0.0 \%$ & $100.0 \%$ & $100.0 \%$ \\
\hline & I eft Parietal I he & $\mathrm{n}$ & 0 & 1 & 1 \\
\hline & Letri antetar Lune & $\%$ & $0.0 \%$ & $100.0 \%$ & $100.0 \%$ \\
\hline & Left Thalamus & $\mathrm{n}$ & 0 & 3 & 3 \\
\hline & & $\%$ & $0.0 \%$ & $100.0 \%$ & $100.0 \%$ \\
\hline & I eft Temnoral I ohe & $\mathrm{n}$ & 1 & 1 & 2 \\
\hline & Leti teminotar Luve & $\%$ & $50.0 \%$ & $50.0 \%$ & $100.0 \%$ \\
\hline Total & & $\mathrm{n}$ & 3 & 38 & 41 \\
\hline Tulal & & $\%$ & $7.3 \%$ & $92.7 \%$ & $100.0 \%$ \\
\hline
\end{tabular}


Table 2. Statistical relationship between the presence of lesions in the sensitive area and whether these lesions can have pathological diagnosis

\begin{tabular}{|c|c|c|c|c|c|}
\hline & & & Patholo & Diagnosis & Tatal \\
\hline & & & No & Yes & IOtal \\
\hline & No & $\mathrm{n}$ & 1 & 14 & 15 \\
\hline Eloquent & 10 & $\%$ & $6.7 \%$ & $93.3 \%$ & $100.0 \%$ \\
\hline Region & Yes & $\mathrm{n}$ & 2 & 24 & 26 \\
\hline & IEs & $\%$ & $7.7 \%$ & $92.3 \%$ & $100.0 \%$ \\
\hline Tatal & & $\mathrm{n}$ & 3 & 38 & 41 \\
\hline total & & $\%$ & $7.3 \%$ & $92.7 \%$ & $100.0 \%$ \\
\hline
\end{tabular}

The mean lesion size was $34 \times 27.76 \mathrm{~mm}$. There was no statistically significant difference between the size of the lesions and the adequacy of the amount of tissue sample for histopathological diagnosis. ( $>0.05$ ) (Table 3). The primary diagnosis of $3(7.31 \%)$ patients was lung cancer; the rest of the patients were undiagnosed. When the results of MR spectroscopy taken before the operation were examined, it was found that the preliminary diagnosis of $11(29.72 \%)$ lesions was undecided ( 3 grade 3 glial masses, 2 grade 2 glial masses, 2 lymphomas, 3 metastases, 1 vasculitis), and the diagnosis of 26 (70.27\%) lesions was sure (17 glioblastoma multiforme (GBM), 4 metastases, 2 lymphomas, 1 grade 2 glial masses, 1 abscess, 1 demyelinating disease). It was determined that 4 patients did not undergo MR spectroscopy before the operation. When the pathology results were examined, it was seen that the tissue diagnosis of $3(7.31 \%)$ patients was uncertain (2 necrotic tissue, 1 insufficient sample), tissue samples taken by NNAB of $38(92.68 \%)$ patients were found to be able to diagnose (19 GBM, 2 grade 2 glial masses, 6 lymphomas, 3 grade 3 glial masses, 4 metastases, 2 demyelinating diseases, 2 abscesses). When the diagnoses of the patients who had both MR spectroscopy and pathology results were compared, the radiological and pathological diagnoses of $27(72.9 \%)$ patients were compatible with each other. The lesions of 8 (19.51\%) patients were cystic. It was determined that the cystic lesions of $6(75 \%)$ patients were evacuated grossly by the NNAB procedure. CT scans taken in the first 24 hours after the operation revealed radiological complications in 4 $(9.75 \%)$ patients ( 2 site hematoma, 1 ventricular hemorrhage, 1 trace hematoma). No relationship was found between the radiological complications after the operation and the location of the lesion and whether it was in the eloquent area or not ( $p>0.05$ ) (Table 4, Table 5). In the postoperative neurological examinations of the patients, neurodeficiency was detected in $3(7.31 \%)$ patients; permanent in 1 patient and temporary in 2 patients. No significant relationship was found between the neurological complications after the operation and the location of the lesion and whether it was in the eloquent area or not ( $p>0.05$ ) (Table 4, Table 5). Of the three patients with neurological deficit, $2(66 \%)$ patients had radiological complications. Besides, it was statistically shown that the size of the lesion was not associated with the development of neurologic and radiological complications after the operation (Table 3). No procedure-related mortality was detected in the patients included in the study. Postoperative wound complications were detected in 2 (4.87\%) patients, 1 of whom was cerebrospinal fluid (CSF) leakage, and the other was local wound infection. It was observed that these wound problems were resolved with simple interventions. The mean postoperative length of hospital stay of the patients was 9.91 days. There was a significant difference between the length of hospital stay of the patients and the length of stay in the Neurosurgery Clinic since approximately $56 \%$ of the patients included in the study were consulted from other clinics and were taken over from these clinics before the procedure and transferred back to these clinics after the procedure. Considering the length of hospital stay due to the NNAB procedure, it would be more accurate to evaluate the length of stay in the Neurosurgery Clinic (Table 6). This period was an average of 4.39 days. No statistically significant difference was found when the length of stay in Neurosurgery Clinic was compared according to whether the lesion was in the eloquent area or the size of the lesion ( $p>0.05)$.

\section{Table 3. Statistical relationship between size of biopsy lesions and} presence of postoperative radiological complication, postoperative neurological complication and pathological diagnosis

\begin{tabular}{llcccc} 
Lesion Size $\left(\mathbf{m m}^{\mathbf{2}}\right)$ & & $\mathbf{n}$ & Mean & Median & $\begin{array}{c}\text { Mann- } \\
\text { Whitney Test } \\
(\mathbf{p})\end{array}$ \\
\hline $\begin{array}{l}\text { Postoperative Radiological } \\
\text { Complication }\end{array}$ & No & 37 & 806 & 450 & 0.629 \\
\hline Yes & 4 & 1886 & 875 & \\
\hline $\begin{array}{l}\text { Postoperative Neurological } \\
\text { Compliacation }\end{array}$ & No & 38 & 928 & 497 & 0.920 \\
\hline Pathological Diagnosis & No & 3 & 704 & 420 & \\
\hline & Yes & 38 & 947 & 497 & 0.652 \\
\hline
\end{tabular}

Table 5. The statistical relationship between the presence of lesions in the sensitive area and whether postoperative radiological complication and postoperative neurological complication

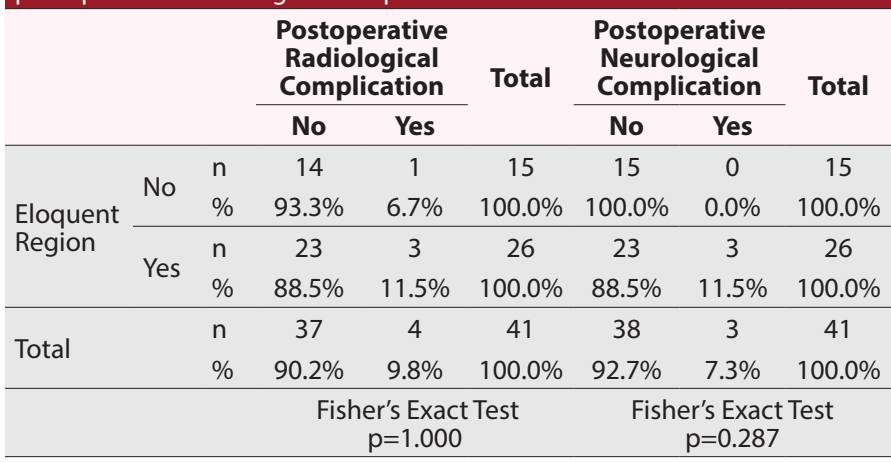

Table 6. The statistical relationship between the presence of lesions in the eloquent area and stay in neurosurgery clinic, lesion size and stay in neurosurgery clinic

\begin{tabular}{|c|c|c|c|c|}
\hline & & & $\begin{array}{c}\text { Stay in Neurosurgery } \\
\text { Clinic (Day) }\end{array}$ & $\begin{array}{l}\text { Fisher's } \\
\text { Exact Test }\end{array}$ \\
\hline \multirow{4}{*}{$\begin{array}{l}\text { Eloquent } \\
\text { Region }\end{array}$} & No & $\mathrm{n}: 15$ & 433 & \multirow{4}{*}{$p>0.05$} \\
\hline & & \%: 36.5 & & \\
\hline & \multirow{2}{*}{ Yes } & $\mathrm{n}: 26$ & \multirow{2}{*}{4.41} & \\
\hline & & \%: 63.5 & & \\
\hline \multicolumn{2}{|c|}{$\begin{array}{l}\text { Lesion Mean Size } \\
\left(\mathrm{mm}^{2}\right)\end{array}$} & $\begin{array}{l}\mathrm{n}<911 \mathrm{~mm}^{2} \\
\mathrm{n}>911 \mathrm{~mm}^{2}\end{array}$ & 4.39 & $p>0.05$ \\
\hline
\end{tabular}


Table 4. The statistical relationship between the location of lesions that have been biopsied and whether postoperative radiological complication and postoperative neurological complication

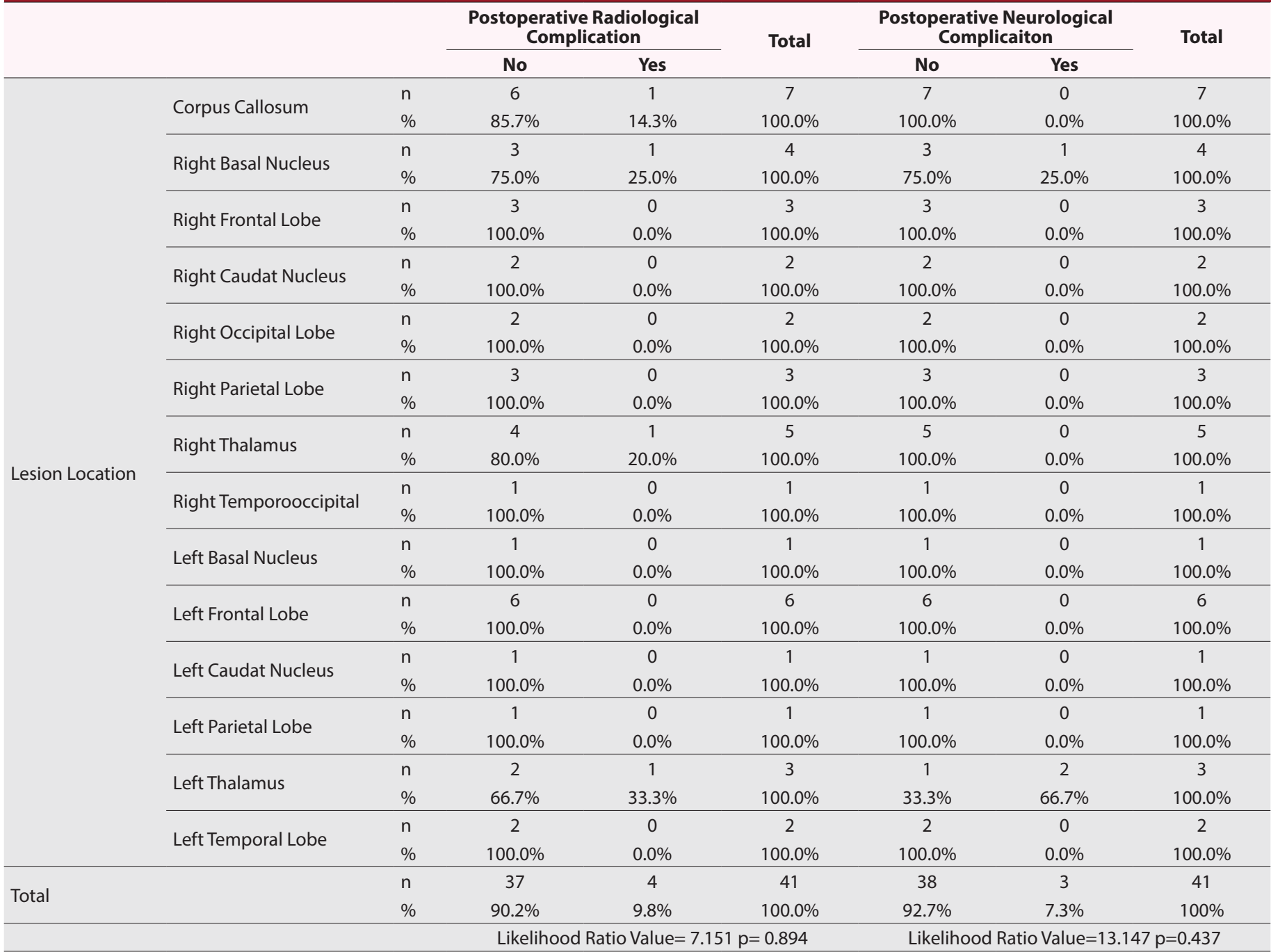

\section{DISCUSSION}

The most important criteria that distinguishes NNAB from surgery performed by craniotomy is to obtain sufficient tissue samples from lesions in deep-seated, small-sized, and so-called eloquent areas. Also, it does not cause additional morbidity or mortality in patients with high comorbidity/ comortality. Although the use of this method has increased considerably in these respects, morbidity rates vary between $1.3 \%$ and $27.8 \%$, and mortality rates vary between $0.7 \%$ and $3.9 \% \cdot{ }^{[2,3]}$ In our study, there was no mortality related to the biopsy procedure, and the morbidity rate was $7.1 \%$. Although our morbidity rates were not statistically significant according to the location of the lesions and their presence in the eloquent area, they were lower than most of those reported in the literature. ${ }^{[2]}$ Since more than half of the patients included in the study [22 (53.65\%) patients] had pre-operative neurodeficiency and $63.41 \%$ of the biopsy taken lesions were in the eloquent area, we believe that it is important that our morbidity remains at $7.1 \%$.
Especially in the biopsy of lesions located in eloquent areas, the possibility of morbidity increases as the size of the lesion decreases. ${ }^{[2]}$ In our study, it was found that postoperative neurological complications developed in 2 (13.3\%) out of 15 patients, especially with lesions of $20 \times 20 \mathrm{~mm}$ or smaller. This rate is above our general morbidity rate. The lesion of 1 of these patients was located in the basal nuclei, while the other was located in the thalamus. In more than $90 \%$ of the studies in the literature, the sizes of the lesions that were biopsied were over $1 \mathrm{~cm}$, which is also consistent with our study. ${ }^{[2]}$ However, contrary to our study, there are also studies stating that biopsies performed using a framed head may be more efficient and safe since the lesion size is small. ${ }^{[47]}$ This also applies to the deeply located lesions and lesions in eloquent areas. ${ }^{[4,8,9]}$ However, the advantages of the two methods over each other are not clear in the literature due to the fact that the results of the frameless method in recent studies are as good as the framebased method results and that the frame-based method has disadvantages for patient comfort, difficulty in imaging, prolonging the surgical time, and the risk of infection. ${ }^{[1,2,10]}$ 
Radiological complications can also be seen in patients without postoperative neurologic complications. As a radiological complication, hemorrhage in the biopsy trace or bleeding into the biopsy taken lesion can be seen (Figure 3). ${ }^{[1]}$ Although these bleedings do not increase most of the time, they can lead to dramatic results such as hematoma needing discharge by craniotomy, neurodeficiency, and even death. ${ }^{[11]}$ Therefore, control cranial CT is performed in the first 3 hours after biopsy in our clinic for early diagnosis, follow-up, and treatment. In this study, we detected hematoma in 4 (9.75\%) patients after the process. However, 2 of them (1 intralesional hematoma, 1 contusion on trace line) had neurological complications. None of these patients required reoperation since there was no increase in hematoma and neurodeficiency in the followup CT scans. Special attention should be paid to biopsy targeting and the absence of vascular formation in the trace to be passed, apart from considering the use of anticoagulant or antiaggregant in patients to prevent such bleeding. Hence, it is necessary to examine the MR images adequately while making the plan. Also, the nature of the lesion from which the biopsy was taken should be considered. ${ }^{[2]}$ The MRI must be taken before the surgery should be interpreted correctly in this respect. In lesions of unknown primary, accurately interpreted radiological examinations can give clues to the surgeon whether the lesion is bleeding or not.
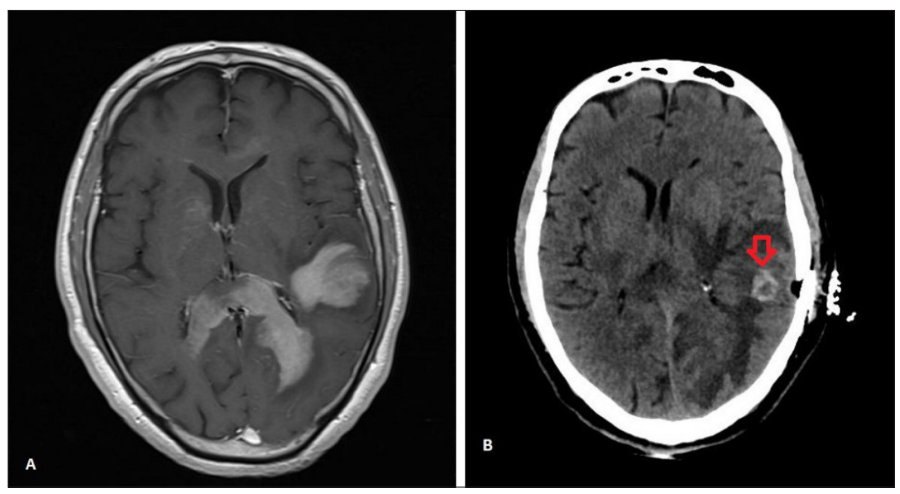

Figure 3. (A) The appearance of the lesions as hyperintense in contrastenhanced T1 axial MRI, (B) Hematoma appearance in the biopsy area in postoperative early control cranial CT.

In our study, the harmony between the preliminary diagnosis stated in MRI spectroscopy and the histopathological diagnosis after the biopsy was approximately $73 \%$. In order to make the correct tissue diagnosis, it is necessary to take sufficient tissue samples from the right part of the lesion. Accurate histopathological diagnosis of the lesion and accurate grading of neuroglial masses is vital for patients to receive valid oncological treatment. ${ }^{[1]}$ However, the amount of tissue samples that can be taken with the NNAB method is very limited due to the thinness of the biopsy needle (Figure 2).

Therefore, if the biopsy is not taken from the targeted lesion are with sufficient quantity, tissue samples can be taken from the cerebral tissue, necrotic part, or areas where the mass grade is low. To prevent this, tissue samples should be taken from different quadrants of the target point (Figure 2). However, there are not enough deterministic studies on this subject in the literature. ${ }^{[2]}$ Our practice is to take a biopsy by rotating the biopsy needle 360 degrees in 4 quadrants. This situation brought the success of histopathological diagnosis with a rate of $92.68 \%$ (Figure 1). Although there are different statements about this rate in the literature, the highest rates vary between $84 \%$ and $100 \%{ }^{[2,10]}$ We think that the correct interpretation of current MR images by the neuroradiologist is important to increase the accurate histopathological tissue diagnosis. It is also very useful to define the highest graded part of the lesion to the surgical team and plan the biopsy target accordingly. Besides, a plan can be made by determining the target in more than one way from a single burr hole to increase the histopathological accuracy of the biopsy. However, it should not be forgotten that each additional intervention to the cerebral tissue increases the risk of complications. ${ }^{[2]}$

The cerebral tissue in which the lesion is located and the size of the lesion are also important for the accuracy of histopathological diagnosis. ${ }^{[10]}$ When the lesion is located in the eloquent area and/or is small in size, the complication risk increases; therefore, sampling from more than one quadrant can be avoided. ${ }^{[2,10]}$ Also, the deeper the lesion and the farther from the cortical area, the greater the amount of cerebral tissue to be passed. Besides, the inconsistency of the cortical anatomy, which corresponds to the entry point in the shortest route plan to reach the lesion, may cause the location of the cortical entry point to be changed and increase the distance to the target. In this respect, some centers perform the biopsy planning on functional MR images to protect the more functional areas of the brain. ${ }^{[3]}$

Also, depending on the patient's brain tissue structure (atrophicity, large cisterna, etc.), the ventricle, and important vascular structures close to the lesion, there may be shifts in different directions from the targeted area on the lesion. In our study, $2(66.6 \%)$ lesions out of the three patients who could not get a histopathological diagnosis were in an eloquent area and deeply located. Besides, the mean size of lesions that could not be diagnosed histopathologically (454 $\mathrm{mm}^{2}$ ) was smaller than the mean sizes of all lesions in the study $\left(911 \mathrm{~mm}^{2}\right)$.

Obtaining sufficient tissue samples with NNAB can be challenging when the solid part of the lesion is too small, and the lesion is dominantly cystic. The cystic part was more common in the lesions of 8 patients in our study. 2 (66.6\%) out of the three lesions that could not be diagnosed due to insufficient tissue samples had cystic structure. One of these lesions was in the eloquent area, and the other was not. Also, 2 of these lesions did not have an apparent solid component. Hence, if the cystic content aspirated by the NNAB method is not histopathologically diagnostic, it may unfortunately also be a disadvantage. However, we have experienced that cystic contents could be drained totally with the NNAB method; 6 $(75 \%)$ of the cystic lesions in our study were almost totally 
drained in the early control CT scans taken after the operation. The lack of studies in the literature on the approach to cystic lesions with the NNAB method is also noteworthy.

In multiple lesions, having more options to obtain sufficient tissue and reaching the target without any problems is an advantage. The lesion should be chosen according to its proximity to the cortex, distance from important structures in the cerebral tissue. Also the largest lesion or the lesion with the most suitable nature for accurate diagnosis should be preferred if possible. ${ }^{[1-3,10]}$ In our study, the mean size of the multiple lesions was $963.8 \mathrm{~mm}^{2}$, which was close to the overall mean size of all lesions. Therefore, biopsy tissues taken from this group were sufficient in quantity, and pathological diagnoses could be made in all of them. In addition, there was only one patient $(10 \%)$ with multiple lesions who had postoperative radiological and/or neurological complications. The lesion that could not be diagnosed due to insufficient tissue sample was not present in this group.

Although there is not enough data in the literature, the mean length of hospital stay of the patients who underwent the NNAB method included in our study was 4.39 days, which was significantly below the mean existing data. ${ }^{[10]}$ This indicates that the procedure-related morbidity is low. Despite the multiplicity of lesions located in the eloquent area from which the biopsy was taken, the average length of hospital stay in our study makes the procedure's minimal invasiveness even more significant.

The results of our study include many important details that will lead to other studies related to the NNAB method. However, no statistically significant difference was found due to insufficient sample size in most of the parameters. According to our literature review, that this situation was also experienced in other trials. ${ }^{[1]}$

\section{CONCLUSION}

Although many factors affect the success of neuronavigation and intracerebral biopsy, the lesion's location, adjacency, and the size of the lesion are also important, as supported by the numerical data results of our study. Good planning before surgery and a detailed examination of radiological images by both the radiologist and the surgeon reduces the risk of radiological and neurological complications caused by the lesion's small size and eloquent localization. Through frameless NNAB, it is possible to achieve the same success as frame-based NNAB without causing additional morbidity and mortality. As in our study, a biopsy of the target tissue from more than one quadrant provides sufficient tissue for histopathological diagnosis and helps to make a more accurate diagnosis. With this method, it is also possible to drain cystic lesions significantly regardless of their location and size.

\section{ETHICAL DECLARATIONS}

Ethics Committee Approval: The study was carried out with the permission of Selcuk University Rectorate Local Ethics Committee (Date: 09.06.2021, Decision no: 2021/35).

Informed Consent: Because the study was designed retrospectively, no written informed consent form was obtained from patients.

Referee Evaluation Process: Externally peer-reviewed.

Conflict of Interest Statement: The authors have no conflicts of interest to declare.

Financial Disclosure: The authors declared that this study has received no financial support.

Author Contributions: All of the authors declare that they have all participated in the design, execution, and analysis of the paper, and that they have approved the final version.

\section{REFERENCES}

1. Sciortino T, Fernandes B, Nibali MC, et al. Frameless stereotactic biopsy for precision neurosurgery: diagnostic value, safety, and accuracy. Acta Neurochirurgica 2019;161(5):967-74

2. Dhawan S, He YY, Bartek J, Alattar AA, Chen CC. Comparison of FrameBased Versus Frameless Intracranial Stereotactic Biopsy: Systematic Review and Meta-Analysis. World Neurosurg 2019;127:607-16.

3. Zhang JS, Qu L, Wang Q, et. al. Intraoperative visualisation of functional structures facilitates safe frameless stereotactic biopsy in the motor eloquent regions of the brain. Br J Neurosurg 2018; 32(4):372-80.

4. Livermore LJ, Ma R, Bojanic S, Pereira EAC. Yield and complications of frame-based and frameless stereotactic brain biopsy - The value of intraoperative histological analysis, Br J Neurosurg 2014;28(5): 637-44.

5. Owen CM, Linskey ME. Frame-based stereotaxy in a frameless era: current capabilities, relative role, and the positive- and negative predictive values of blood through the needle. J Neurooncol 2009;93(1):139-49.

6. Grunert P, Espinosa J, Busert C, et. al. Stereotactic biopsies guided by an optical navigation system: technique and clinical experience. Minim Invasive Neurosurg 2002;45(1):11-5.

7. Raabe A, Krishnan R, Zimmermann M, Seifert V. Frame-less and framebased stereotaxy? How to choose the appropriate procedure. Zentralbl Neurochir 2003;64(1):1-5.

8. Smith JS, Quiñones-Hinojosa A, Barbaro NM, McDermott MW. Framebased stereotactic biopsy remains an important diagnostic tool with distinct advantages over frameless stereotactic biopsy. J Neurooncol 2005;73(2):173-9.

9. Dorward NL, Paleologos TS, Alberti O, Thomas DG. The advantages of frameless stereotactic biopsy over frame-based biopsy. Br J Neurosurg 2002;16(2):110-8.

10. Bishokarma S, Shrestha P, Koirala S, Raut M, Gongal DN. Venture in 101 cranial punctures: A comparative study between frame-based versus frameless biopsy of 101 intracranial space occupying lesion. Asian J Neurosurg 2019;14(1):175-80.

11. Krieger MD, Chandrasoma PT, Zee CS, Apuzzo ML. Role of stereotactic biopsy in the diagnosis and management of braintumors. Semin Surg Oncol 1998;14(1):13-25. 